\title{
CATEDRÁTICOS, GUERRAS E GENTES: NOTAS SOBRE LITERATURA COMPARADA E A PESQUISA NO BRASIL
}

\author{
PROFESSORS, WARS AND PEOPLE: NOTES ON \\ COMPARATIVE LITERATURE AND RESEARCH IN \\ BRAZIL
}

\author{
Andrea Cristiane Kahmann \\ Universidade Federal de Pelotas, UFPel, Pelotas, RS, Brasil
}

\begin{abstract}
Resumo: Este artigo busca refletir sobre a história da Literatura Comparada como disciplina e sua consolidaçấo na universidade brasileira, abrangendo seus temas, suas inter-relaçóes e os desafios a serem enfrentados pelo pesquisador comparatista contemporâneo.
\end{abstract}

Palavras-chave: Literatura Comparada; História da Literatura Comparada; Identidades.

Abstract: This paper proposesananalysis on the history of Comparative Literature as a discipline and its consolidation in the Brazilian university, covering its themes, their interrelationships and the challenges to be faced by the contemporary comparative researcher.

Keywords: Comparative Literature; History of Comparative Literature; Identities.

Um dos adventos mais surpreendentes (e medonhos) do século XX foi a tecnologia de impessoalização da guerra, que tornou suas vítimas invisíveis. Matar e destruir remotamente não implicava grandes esforços se não o de cognitivamente conceber que o morto ali era um Outro, que mereceu ser atacado porque morador de um pedaço de terra transformado em inimigo:

\footnotetext{
Lá embaixo dos bombardeios aéreos estavam não as pessoas que iam ser queimadas e evisceradas, mas somente alvos. Rapazes delicados, que certamente náo teriam desejado enfiar uma baioneta na barriga de uma jovem aldeã grávida, podiam com muito mais facilidade jogar altos explosivos sobre Londres ou Berlim, ou bombas nucleares em Nagasaki. Diligentes burocratas alemães, que certamente teriam achado repugnante tanger eles próprios judeus mortos de fome para abatedouros, podiam organizar os horários de trem para o abastecimento regular de comboios da morte para os campos de extermínio poloneses, com menos senso de envolvimento pessoal. As maiores crueldades de nosso século foram as crueldades impessoais, decididas a distância, de sistema e rotina, sobretudo quando podiam ser justificadas como lamentáveis necessidades operacionais (HOBSBAWM, 1995, p. 57).
} 
No pós-guerra (e a partir de suas liçôes), houve uma "extraordinária expansão da educação superior” (HOBSBAWM, 1995, p. 492). Isso não seria, porém, uma consequência da tomada de consciência histórica sobre os caminhos empreendidos pela humanidade e do dever de educar para a paz. Embora ainda náo houvesse associaçáo intrínseca entre ensino superior e pesquisa científica, o mundo que experienciava a corrida armamentista e as investidas espaciais concentraria esforços na formação de quadros altamente capacitados e aptos a inserir a naçáo no jogo do que se convencionou chamar de guerra fria.

No Brasil, entre 1946 a 1964, houve a criação de 19 universidades federais, expansão que, em números absolutos, só ficou atrás do período compreendido entre 1995 a 2014, que recebeu 24 novas universidades (MINISTÉRIO DA EDUCAÇÃO, 2012, gráfico XI). Em 1951, houve a criação da CAPES e do CNPq. No entanto (e reflexo doméstico da mentalidade armamentista), foi somente durante a ditadura militar, após 1964, que a Pós-Graduação no Brasil se consolidou. Segundo informaçôes disponíveis no próprio site da CAPES (em "História e missão"):

O ano de 1965 é de grande importância para a pós-graduação: 27 cursos são classificados no nível de mestrado e 11 no de doutorado, totalizando 38 no país. O desenvolvimento da pesquisa visava a transformaçóes nas tecnologias das forças produtivas e dos aparatos bélicos, o que explicava não apenas o fomento, mas também a institucionalização, ou imposiçáo de mecanismos de controle, por parte do Poder Público (CAPES, 2017).

Sob o viés social, é possível dizer que, pretendendo "espanar" a ignorância herdada dos tempos de colônia ${ }^{1}$, a universidade terminou por cumprir a função de treinar (e perpetuar) elites. Apesar disso, e em um

\footnotetext{
${ }^{1}$ Segundo José Murilo de Carvalho, "a Coroa portuguesa, em contraste com a espanhola, não permitiu jamais a criação de universidades na colônia. $\mathrm{Na}$ época da Independência, havia 23 universidades na parte espanhola e nenhuma na parte portuguesa. Cerca de 150 mil pessoas haviam se formado nas universidades coloniais espanholas, ao passo que apenas 1.242 brasileiros tinham passado pela Universidade de Coimbra. O Brasil independente não alterou radicalmente essa política. Apenas quatro escolas superiores foram criadas até 1830 e as primeiras universidades só apareceram no século XX. A educação superior pública manteve sua função de treinar elites" (CARVALHO, 2007, p. 23).
} 
Brasil majoritariamente católico ${ }^{2}$, rural $^{3}$ e com poucos leitores ${ }^{4}$, os cientistas brasileiros e as suas autorrepresentaçóes de grupo social diferenciado construíram identidade articulada à ideia de neutralidade:

Se os cientistas têm como "missáo" o "desenvolvimento" (idealizado como objeto abstrato e universal), e o instrumento para realizaçâo desta tarefa é um saber específico, calcado nos princípios do método e da razão, logo, a sua atividade é "altruísta", pressupondo não só o distanciamento dos interesses ligados a outras esferas, como a política e a economia, mas também estabelecendo uma hierarquização de valores (LARRATEA, 2012, p. 65).

Foi por meio de vínculos com o chamado setor "produtivo" (isto é, o mercado, a indústria) e em articulação com os militares, que se institucionalizou a pesquisa no Brasil e se alçou o nacionalismo a novos patamares por meio da construçáo de uma nova imagem social da ciência - supostamente neutra. Que neutralidade haveria, contudo, na pesquisa adstrita à lógica "pragmático-utilitária" (SCHMIDT, 2013, p. 304) do "empresariamento da ciência" (SCHMIDT, 2013, p. 304) e da "mercantilização do saber, submetida à necessidade de atender às demandas do mercado com suas redes materiais/sociais" (SCHMIDT, 2013, p. 304)? A que $(\mathrm{m})$ servia o conhecimento produzido na universidade brasileira? Essas e outras questóes seriam propostas no polo oposto ao do setor produtivo, nas chamadas áreas "humanas" do saber, vocacionadas a questionar as crenças e realidades que, de tão entranhadas, só se tornam perceptíveis ao olhar treinado.

Contudo, também as ciências humanas foram (e são, ainda, por certo) eivadas de doxas e sujeitas aos afâs nacionalistas. Muitas Escolas de lugares determinados funcionaram como disputa entre torcidas, e pensadores de prestígio só alçaram tal status porque "teorizavam" no idioma do capital internacional. O desabafo de Spivak (2005, p. 57-58) é contundente: "Às vezes leio e ouço que o subalterno pode falar em suas línguas nativas. Eu gostaria de poder ter essa autoconfiança tão firme e inabalável que têm o intelectual, o crítico literário e o historiador que, aliás, afirmam isso em inglês. Nenhuma fala é fala enquanto não é ouvida”. Mais que todos os

\footnotetext{
${ }^{2}$ Os católicos foram esmagadora maioria até os anos 1970 (92\%) (SILVA; BARBOSA, 2006, p. 54).

${ }^{3}$ Conforme SILVA e BARBOSA, L. O., 2006, p. 49, "enquanto a populaçấo classificada como urbana em 1950 correspondia a cerca de $36 \%$ do total da populaçăo brasileira, a cifra referente ao ano 2000 atingia mais de $81 \%$ ".

${ }^{4}$ Foi somente no Censo de 1960 que se constatou, pela primeira vez, que o número de brasileiros alfabetizados havia superado o de analfabetos (dados do IBGE).
} 
ismos que marcaram o século XX, os nacionalismos ocuparam um espaço privilegiado após o colapso dos grandes impérios multinacionais europeus, a Revolução Russa e o advento das tecnologias de comunicação de massa, que romperam os limites entre esferas pública e privada, e fizeram da cultura (e da literatura, como espaço privilegiado a confluir o histórico e o mítico) um aparato ideológico a primar pelo controle e vinculação ao "caráter nacional" e às "tradiçốes inventadas" (HOBSBAWM; RANGER, 1984, p. 19).

As literaturas serviram aos nacionalismos como estratégia de identificação cultural e de interpelação discursiva para legitimar a atuação do Estado e inscrevê-la como fruto de uma vontade coletiva. Toda nação é o produto de uma narrativa (BHABHA, 1998) e, nesse processo, abafa-se a voz do Outro: elimina-se o que não é nativo para construir o "nacional por subtração" (SCHWARZ, 2001).

Nos cursos de Letras, em que os estudos eram (como ainda são) determinados por aspectos de ordens culturais e linguísticas a se reforçarem mutuamente, os escritores usualmente recebem rótulos e alcunhas associadas a suas naçóes/etnias de origem e, do mesmo modo, as línguas nacionais valorizam-se e podem ser referidas pelos fundadores da literatura nacional (é assim que o português transforma-se em "a língua de Camôes"). O cânone, a "elite" das obras literárias, e a visáo que leitores (profissionais e não-profissionais) dele assumem era (como ainda é) um construto "frequentemente baseado de forma frouxa em algumas passagens selecionadas do livro em questão [...], suplementado por outros textos que reescrevem o original" (LEFEVERE, 2007, p. 20). Incluindo obras lidas por raríssimos, mas alardeadas (e defendidas) por diversos leitores nacionais, o cânone cumpriu sua missão de amalgamar a nação; compunha-se por obras que negavam (ou escondiam) sua vinculação (ou dependência) em relação ao político e que, no mais das vezes, eram escritas no idioma do dominador por homens brancos heterossexuais pertencentes a (ou apadrinhados) pelas elites.

A tensão entre centro e periferia desde sempre se definiu por relações de poder. Assim, cultura (e, especialmente, cultura oficial) remete ao repertório dos grupos dominantes; a periferia (ou subcultura), a seu turno, conformaria uma categoria exterior ao sistema, ou às margens deste, quando vista desde dentro, pelas pessoas-na-cultura, traduçáo nossa para people-in-the-culture, conforme definição de Lotman e Voegelin, citada por Even-Zohar (2013). Cultura oficial ou dereferência é o cânone; a literatura popular, o cordel, a pajada, a narrativa produzida por ou para mulheres, crianças e diferentes [sic] em geral, a qual só pode ser relegada às margens. No entanto, os papéis que 
uma determinada obra pode desempenhar em um determinado tempo e lugar não são estanques, como a História da Literatura e a própria Literatura Comparada encarregaram-se de demonstrar por diversas vezes.

No que tange à Literatura Comparada, é preciso recordar que:

Como uma área do saber literário de origem europeia que iniciou sua história no século XIX, o século dos nacionalismos por excelência, a literatura comparada inovou precisamente quando se propôs a pensar uma literatura nacional para além de suas fronteiras linguístico-estéticas, geográficas e políticas, a partir de fontes e influências, paradigma hoje ultrapassado por seus compromissos com o pensamento binário implícito na visão etnocêntrica, mas que, na época, constituiu um modelo teórico importante por colocar em destaque a rede de múltiplas relaçôes constitutivas do literário (SCHMIDT, 2013, p. 307).

Embora suas origens remetam ao século XIX, a consolidação dos estudos comparatistas nas universidades deu-se no século XX, sob o signo da diáspora e da exclusão5. Já é um lugar-comum o "mito de origem" da Literatura Comparada nos Estados Unidos: exiliados e emigrados, como Leo Spitzer e Erich Auerbach, teriam-na fundado e dissipado com base em ideias nostálgicas e igualmente questionáveis como nação, lar, comunidade e pertencimento. Contudo, sobretudo após 1970, teóricos de renome internacional alçaram vozes contra o teor etnocêntrico da disciplina, e esta passou a valorar os vínculos entre a literatura e a cultura, a política e a história das ideias (ALÓS, 2012). Foi nos anos 1970 que se acentuaram os confrontos entre Literatura Comparada e Estudos Culturais (CARVALHAL, 2003, p. 211) e disso culminou a tomada de consciência em relação ao papel político da literatura e a abertura do campo aos debates acadêmicos mais amplos das ciências humanas (ALÓS, 2012).

\footnotetext{
${ }^{5}$ Nas palavras de Steiner: "Não é segredo algum que estudiosos judeus ou de origem judaica têm com frequência desempenhado papel de destaque no desenvolvimento da literatura comparada como área acadêmica. [...] Dotado, ao que parece, de uma facilidade incomum no aprendizado de línguas e forçado a ser um frontalier (palavra triste de origem suíça para quem, material ou psicologicamente, precisa viver próxima à fronteira ou tenta equilibrar-se sobre ela), o judeu do século XX é particularmente atraído pelo conhecimento e a comparação de literaturas seculares que ele preza muito, mas que em nenhum caso lhe pertencem "por direito de herança nacional". Forçados a exilar-se - uma obra-prima da literatura comparada, Mimesis, foi escrita na Turquia por Auerbach, um refugiado que, da noite para o dia, viu-se privado de seu meio de vida, de sua língua natal e de sua biblioteca - os judeus (os meus próprios professores) que tiveram a sorte de chegar à América do Norte lá encontrariam os tradicionais Departamentos de Literaturas das universidades, em especial os de língua inglesa, com portas fechadas para eles. Portanto grande parte dos futuros programas ou departamentos de literatura comparada no mundo acadêmico americano teve origem na marginalidade, na exclusão parcial de caráter étnico e social" (STEINER, 2001, p. 156).
} 
As décadas de 1960 e 1970 testemunhariam, também, o chamado boom da literatura latino-americana, marcado pelo inédito interesse estrangeiro na tradução de autores da América Latina, inclusive (ainda que em bem menor escala) do Brasil. Torres (2014, p. 56-57) associou o fenômeno ao acento político à cooperaçáo após os golpes de Estado que massacraram diversos países e encadeou expressivo número de exilados na França.Pode ser, ainda, que tenha sido "o júri do Prêmio Nobel de literatura, um corpo cujo senso político em geral é mais interessante que seus julgamentos literários" (HOBSBAWM, 1995, p. 485) a conferir prestígio às letras latino-americanas: Gabriela Mistral já tinha sido laureada em 1945, Miguel Ángel Asturias receberia o Nobel em 1967 e Pablo Neruda, em 1971. Gabriel García Márquez (1982), Octavio Paz (1990) e Mario Vargas Llosa (2010) seriam fenômenos posteriores; mesmo assim, e em que pese dois dos três prêmios tenham sido concedidos a poetas, na análise de Hobsbawm: "nenhum leitor sério de romances podia, na década de 1970, ter deixado de entrar em contato com a brilhante escola de escritores latino-americanos" (HOBSBAWM, 1995, p. 485).

É impossível, hoje, dimensionar o impacto à época de ver-se o escritor latino-americano sendo lido e reconhecido na república mundial das letras, conforme as palavras de Pascale Casanova: a França, o meridiano de Greenwich da literatura, por meio do qual todos os ponteiros deveriam se acertar. Segundo ela, "a particularidade do capital literário 'francês' é de ser também patrimônio universal, isto é, constitutivo (e, no caso francês, fundador) da literatura universal e não nacional" (CASANOVA, 2002, p. 115). Deixando para outro artigo a problemática visão de superioridade nacional ainda presente nesse estudo de Casanova, é preciso reconhecer que o boom da literatura latino-americana teve lugar junto a diversos questionamentos sobre o cânone mundial, e pilares como centro x periferia, a nortear os julgamentos sobre a escrita criativa. A formação do cânone e a recepçáo das obras literárias não mais poderiam ser explicadas pelo ingênuo construto de mérito literário puro e simples. Teóricos de língua espanhola, como Ana Pizarro e Antonio Cornejo Polar, ainda que de modos diferenciados, impuseram o questionamento dos cânones literários eurocêntricos e, junto a isso, questionaram o próprio cânone literário latinoamericano, colocando em pauta a literatura oral, o folclore, o cordel e outras modalidades de literaturas "populares" (ALÓS, 2012, p. 27).

Após a legitimação pelo eixo euro-norte-americano, o Brasil se abriria aos escritores dos países vizinhos de língua espanhola. O (hoje) incontestável Jorge Luis Borges somente em 1970 receberia a sua primeira tradução em livro: Ficçóes (de 1944) foi traduzido por Carlos Nejar (VALLERIUS, 
2010, p. 222) e alvoroçou as letras brasileiras. Vivia-se "a fase mais negra da ditadura militar, entre 64 e 74, com toda a sua carga de opressão, exílio e censura" (BOSI, 2007, p. 435) e o esvaziamento, por susto, da narrativa brasileira. Apesar disso, e impulsionada pelo milagre econômico, "para a indústria e comércio do livro, o resultado líquido das políticas do novo regime militar, no período de 1964 - 1973, foi uma notável expansão" (HALLEWELL, 2012, p. 629). As tiragens de traduçóes brasileiras voltavam a crescer, e, com elas, chegavam novas ideias, gêneros e formas, cumprindo a missão involuntária da tradução que é transgredir fronteiras, contrabandear visões de mundo. Embora seja sabido que as traduçóes podem desempenhar função reacionária e reforçar cânones domésticos, sempre deixam entrever algo do Outro, de sua forma de pensar e escrever. E a Literatura Comparada, desde sempre ocupada com as travessias e subversóes de fronteiras entre línguas, culturas e áreas do saber, ganharia novo fôlego com as traduçôes e o fortalecimento dos Estudos de Tradução como campo disciplinar.

As aproximaçóes entre literatura comparada e estudos de tradução sempre foram tantas e tão profundas que Susan Bassnett chegou a sugerir que aquela poderia ser considerada "um ramo dessa disciplina muito mais abrangente que é a dos Estudos de Tradução" (BASSNETT, 1991, p. XVI). Em 2006, a autora reformulou essa afirmação para concluiu que nem a literatura comparada nem os estudos de tradução deveriam ser vistos como disciplinas autônomas. Reafirmou, porém, que a história da tradução é central em todo estudo literário comparativo, e grandes períodos de inovação literária tendem a ser precedidos por intensa atividade tradutória (BASSNET, 2006, p. 0). Os românticos alemães já haviam alcançado essas conclusóes e, ainda antes deles, os antigos romanos tinham-se constituído como cultura a partir de um imenso trabalho de tradução/assimilação dos gregos.

Para Seligmann-Silva, o espírito do final do século XVIII estava associado ao conceito de "Bildung (formação-cultura) de uma nação como dependente de sua capacidade não tanto de abrir-se ao outro, ao estrangeiro, mas, sobretudo, como capacidade de sair de si, de passar para o estrangeiro, de Über-setzung" (SELIGMANN-SILVA, 2005, p. 171), termo que implica trans-posição e que costumamos traduzir por tradução. O alvorecer da Literatura Comparada como disciplina, no século XIX, esteve imbuído desse conceito.

Para Goethe, Humboldt e Herder, "a faculdade de criar palavras, o impulso no sentido da inovação verbal, da organização léxica e sintática em modelos formais de métrica e musicalidade é um fenômeno universal" 
(STEINER, 2001, p. 154) e, portanto, nada mais óbvio que o estudo da literatura partir, também, de pressupostos universais. Afinal, o "estudo de outras línguas e de suas traduçôes literárias, a apreciação do seu valor intrínseco e do que se entretece na teia dos valores universais interpretando a condição humana" (STEINER, 2001, p. 155) diz respeito à humanidade como um todo. Eram essas ideias que eles insistiam em disseminar em face ao isolamento e à arrogância decorrentes dos nacionalismos:

\begin{abstract}
Como os alquimistas, que ele lia com muito interesse, Goethe acreditava nas inter-relaçóes e nas harmonias ocultas de tudo que existe. A voz da natureza pode ser melhor ouvida em grandes acordes e em uníssono. Weltliteratur e Weltpoesie implicam uma conjectura, não muito discernível, quanto à existência de universalidades comuns subjacentes às diversas línguas e dela geradoras e que ocasionam afinidades estruturais e evolucionárias subterrâneas até mesmo entre as mais formalmente remotas. $\mathrm{O}$ ecumenismo de Goethe decorre de sua postura moral e política. No fim da década de 1820 , esse ser olímpico, já velho e bastante isolado - isolado por sua fama mundial -, passou a ver com grande apreensão as forças nascentes do nacionalismo e do chauvinismo militante que se puseram em marcha na Europa pós-napoleônica e, em especial, na Alemanha. Ele conhecia e temia a verbosidade teutônica e o fervor retrógrado das novas filologia e historiografia germânicas (STEINER, 2001, p. 155).
\end{abstract}

Foi dessas apreensóes que se originou o termo literatura-mundo (Weltliteratur), uma literatura universal, desde as origens associada à traduçáo e à angústia entre ser fiel ao caráter do original ou a suas palavras, dúvida diante da qual Humboldt posicionava-se favorável ao primeiro: "fidelidade deve ser dirigida ao verdadeiro caráter do original, o qual não deve ser abandonado em favor de seus elementos fortuitos" (HUMBOLDT, 2010, p. 111). Dizia mais: "Pode-se até mesmo afirmar que uma tradução se torna tanto mais desviante quanto maior o seu esforço para alcançar fidelidade" (HUMBOLDT, 2010, p. 107). Humboldt e seus contemporâneos Goethe e Schleirmacher defendiam a tradução (e a leitura da literatura-mundo) como estratégia de enriquecimento da língua e ampliação dos horizontes de um povo. Assim, prenunciavam o que Bassnett, quase dois séculos depois (no citado discurso à Associação Britânica de Literatura Comparada, em 2006), defenderia: é por meio da tradução, da leitura da literatura-mundo, que chegam novas ideias, gêneros e formas que redefinem naçóes, seus povos e suas escritas.

O espanto de ler, nos clássicos do início do século XIX, respostas tão convictas para questóes sobre as quais a pesquisa em Letras refletiu com intensidade nas últimas décadas do século XX demonstra o quanto a 
falaciosa estipulação de hierarquias entre naçôes, obras literárias e campos do saber souberam desviar o foco das reflexóes. Um século depois de Goethe, o ideário germânico seria outra vez acossado pelos (ainda mais histriônicos) nacionalismos e suas mazelas. Walter Benjamin, seguramente sob inspiração de Goethe, conceberia seu célebre ensaio $A$ tarefa do tradutor, no qual elaboraria seu arcabouço teórico metafísico calcado na ideia de uma língua pura e universal (ou seja: desprovida de bandeiras, hinos e naçóes), rumo à qual a tradução faria elevar-se uma obra. Impossível não evocar o mito bíblico de Babel e o castigo à arrogância do homem daqueles tempos de guerra total em que batalhas eram estaladas sem aviso prévio, sem tratados ou negociaçóes, sem distinção entre combatentes e não combatentes (HOBSBAWM, 1995). O homem do início do século XX acabou por habituar-se às barbáries que teriam escandalizado os ancestrais do século XIX. Assim, "no início do século XX, a tortura fora oficialmente encerrada em toda a Europa Ocidental. Depois de 1945, voltamos a acostumarnos, sem grande repulsa, a seu uso em pelo menos um terço dos Estados membros das Naçóes Unidas, incluindo alguns dos mais velhos e civilizados" (HOBSBAWM, 1995, p. 56). O início do século XX demonstrou que seres humanos precisariam aprender a viver nas condiçóes mais brutalizadas e nunca antes imaginadas como produtos de uma civilizaçâo. $\mathrm{O}$ final do século $\mathrm{XX}$, porém, e os rumos do capitalismo do pós-guerra náo fizeram melhor.

A globalização e a consequente transnacionalização da economia subverteram as lógicas até então impostas, e fez com que os Estados se vissem obrigados a se inserir nos mercados, e não o contrário (HABERMAS, 2003, p. 103-104). Esse contexto marcou a derrocada do nacionalismo em sua conotação originária, para o que, ponderava Kliksberg (1998), contribuiu o desmonte da estrutura estatal e a sua ineficácia ante o cumprimento das funçôes sociais ${ }^{6}$. A insatisfação da sociedade civil com o Estado reduzido ao

\footnotetext{
${ }^{6}$ Alguns dados citados por Kliksberg (1998, p. 12-16) ilustram a crise de funcionalidade do Estado ao final do século XX: 1,3 milhão de habitantes do planeta recebiam uma renda menor do que um dólar por dia, dois quintos da população mundial não dispunham de serviços sanitários adequados e de eletricidade, 800 milhóes de pessoas náo recebiam alimentação suficiente e cerca de 500 milhōes estavam em estado crônico de desnutrição. Por ano, 17 milhôes de pessoas morriam a causa de infecçôes e doenças parasitárias curáveis, como diarreia, malária e tuberculose. Dados da OIT demonstravam que um terço das crianças dos países em desenvolvimento era mal nutrido e que a taxa de mortalidade infantil desses países era de 97 por mil. 600 mil crianças morriam por ano devido a causas evitáveis na América Latina. O World EmploymentReport da OIT mostrava, ainda, que, em 1995, 30\% de toda a mão-deobra do mundo estava desempregada ou subempregada. Nesse quadro, os $20 \%$ mais pobres do mundo detinham um volume de renda equivalente a $1,45 \%$, enquanto os $20 \%$ mais ricos detinham $85 \%$ da riqueza mundial. Em outras palavras: 358 multimilionários concentravam um patrimônio superior à renda acumulada de $45 \%$ da população mais pobre do mundo $(2,3$
} 
mínimo, subordinado às relaçóes econômicas transnacionais e já sem forças de associar os símbolos de orgulho nacional às suas razóes, provocou a perda da credibilidade que atingiu a esfera pública em geral.

A produção cultural inseriu-se na era da globalização sob essas contradiçóes. A aceleração generalizada dos tempos de giro do capital acentuou a volatilidade e a efemeridade do viver, pensar e sentir. Em termos de mercado, fez-se a passagem entre o acúmulo de bens para o consumo de serviços, inseridos na lógica do efêmero e do descarte: do ser capaz de se desfazer de "estilos de vida, relacionamentos estáveis, apego a coisas, edifícios, lugares, pessoas e modos adquiridos de agir e ser" (HARVEY, 1992, p. 258). Uma das consequências mais imediatas desse fenômeno foi o descentramento do sujeito (JAMESON, 1997, p. 42) e o recalque (em acepção freudiana) do sentir.

A desestabilização das posiçôes sociais ocupadas pelos indivíduos na comunidade constituiu-se um dos principais pilares da crise das identidades pós-modernas:

\footnotetext{
Quanto maior a efemeridade, tanto maior a necessidade de descobrir ou produzir algum tipo de verdade eterna que nela possa residir. $\mathrm{O}$ revivalismo religioso, que se tornou muito mais forte a partir do final dos anos 60 , e a busca de autenticidade de autoridade na política (com todos os seus atavios de nacionalismo, localismo, admiração por indivíduos carismáticos e "multiformes" com sua "vontade de poder" nietzschiana) são casos pertinentes. $\mathrm{O}$ retorno do interesse por instituiçôes básicas (como a família e a comunidade) e a busca de raízes históricas são indícios de procura de hábitos mais seguros e valores mais duradouros num mundo cambiante (HARVEY, 1992, p. 263-264).
}

Associando-se a problemática das identidades na pós-modernidade ao acúmulo já proporcionado pelas discussóes comparatistas em nível mundial, não se pôde refrear a assunção, também no Brasil, de um debate mais comprometido com a dimensão política da literatura. Quando os próprios Estados eram empurrados às margens, precisando-se defender da economia mundial e das instituiçóes construídas para remediar suas próprias fraquezas, como é o caso da União Europeia (HOBSBAWM, 1995, p. 554), a pesquisa comparatista e sua desde sempre missão de transgredir fronteiras encontraram terreno profícuo até mesmo no Brasil.

Nos princípios do século XXI, Rodrigues observava que "no panorama dos eventos da área dos Estudos Literários e Comparados no Brasil, realizados nos últimos anos, a questão da identidade nacional surge como um dos tópicos centrais, senão como o tema aglutinador" (RODRIGUES, bilhōes de pessoas). 
2003, p. 109). A questấo das identidades era um "tema quente" nos estudos acadêmicos, mas ainda muito recente. Apenas na década de 1990, e, na esteira de Bhabha, é que, segundo Carvalhal, tinham assumido importância os teóricos da identidade, tanto a nacional como as adstritas a "gender, class, orrace como totalidades sociais” (CARVALHAL, 1997, p. 296). O uso dos termos em inglês, nesse texto de 1997, denuncia que, na virada dos séculos XX para o XXI, ainda havia pudores em referir gênero, classe e raça como temas de interesse da pesquisa no Brasil. É como se fosse necessária a legitimação dos teóricos e das universidades estrangeiras para promover, entre nós, esse debate; a gramática intelectual do Brasil, o nosso ambiente político e as aberturas e trocas possíveis na pesquisa universitária ainda não davam conta desses conceitos.

A discussão sobre a mulher e a literatura, o primeiro pilar dos enfoques identitários a se firmar entre nós, construiu-se com base em muito esforço. Em 1983, a professora Rita Schmidt já havia defendido, em Pittsburgh (EstadosUnidos), sua tese doutoral intitulada "With the sword in my hand": the politics of race and sex in the fiction of Zora Neale Hurston. Apesar disso, quando do regresso ao Brasil, tentou instituir uma linha de pesquisa sobre mulher e literatura da Pós-Graduação da UFRGS; foi, então, ridicularizada por seus pares. Como a própria pesquisadora reconheceu, em entrevista a Priscila Pasko: "No final da década de 1980 tivemos várias reunióes de debate. Eu e a Marcia Navarro, que faleceu em 2010, éramos chamadas de ideológicas, as terroristas da academia" (SCHMIDT, 2015). A linha de pesquisa foi criada, assim como se estabeleceu, durante o primeiro congresso da ANPOLL (Associação Nacional de Pós-Graduação e Pesquisa em Letras e Linguística), em 1986, o GT Mulher e Literatura, que teve Rita Schmidt como cofundadora. Três décadas depois, porém, assistimos ao ressurgimento do que Rita Schmidt refere eufemisticamente como sendo um "cenário perturbador":

Falar sobre literatura, raça e gênero e colocar lado a lado a questáo da autoria feminina sempre significaram para mim, ao longo de minha trajetória como docente e pesquisadora, enfrentar muitas formas de resistência em espaços institucionais. E parece-me que hoje, apesar dos tantos avanços no campo da teoria e de tantas pesquisas relacionadas com esses temas, há um recrudescimento dessa atitude. É um cenário perturbador, e eu, sinceramente, năo tenho condiçóes de dar alguma resposta pontual exceto levantar a hipótese de que em uma sociedade náo pacificada, com desigualdades gritantes e com uma história de centralizações e marginalizaçóes, não se poderia dizer que a discriminação e o preconceito ganham forma apenas no campo social e que o trabalho na academia está isento no que se refere a essas questóes (SCHMIDT, 2016, p. 257-258). 
Quando o protofascismo volta a mostrar suas garras, quando, nas redes sociais, abertamente se convoca ao linchamento (se não real, ao menos moral) dos professores das áreas humanas do saber, quando a crueldade volta a insurgir sob discursos que a defendem como necessidades operacionais, quando as vítimas da tecnologia mais uma vez são tornadas invisíveis e o Outro é atacado simplesmente por sua Outreidade, torna-se difícil espanar o pessimismo. Sentimos como se houvesse uma força maléfica a despertar monstros a cada século: sabemos das angústias de Goethe, naquela década de 1820, e das de Benjamin, nos anos de 1920; depois, percebemos que as visóes universalistas e integradoras do nosso tempo estão sendo constantemente atacadas enquanto marchamos rumo a 2020. Causa ou consequência de uma sociedade não pacificada, o preconceito não está apenas no campo social e já não se esforça por modular discursos nem na academia; reacenderam-se os atavios belicistas e os sectarismos calcados na presunção de superioridade de uns frente a outros. Quando a falaciosa neutralidade procura silenciar o pesquisador que evidencia o seu lócus de enunciação, e são taxados de ideológicos os trabalhos que expóem fraturas sociais, a Literatura Comparada não salva, mas, ao menos, fornece a nós aparatos para eleger o lado da história em que pretendemos estar. Além disso, se questôes como gênero, classe e raça, identidades, enfim, conformaram o cerne das pesquisas comparatistas nos últimos anos, é porque esse campo de estudos sempre esteve ocupado em ouvir a voz da natureza em uníssono, sem estabelecer hierarquias, e deixando dialogarem as diferenças. Eis a literatura-mundo, patrimônio da humanidade inteira para leituras de todos, inclusive das mulheres pesquisadoras que, como eu, têm priorizado, em suas pesquisas, análises outras, não calcadas em teorias de gênero, classe e raça. Pois se hoje, as mulheres predominamos nos cursos de Letras e fazemos ouvir nossa voz, nossos pressupostos teóricos, nossos temas e nossa escrita criativa é porque tivemos precursoras como a professora Rita Schmidt a deitar o olhar atento, paciente e escrupuloso às crenças e às realidades invisíveis aos demais.

\section{Referências}

ALÓS, Anselmo Peres. Literatura Comparada ontem e hoje: campo epistemológico de ansiedades e incertezas. Organon, Porto Alegre, UFRGS, v. 27, n. 52 , p. $17-42,2012$.

BASSNETT, Susan. Prefácio à edição revista (1991). In: Estudos de traduçáo: fundamentos de uma disciplina. Tradução de Vivina de Campos Figueiredo. Lisboa: Fundação Calouste Gulbenkian, 2003. p. XV-XXVII. 


\section{Reflections on Comparative Literature in the Twenty-First}

Century. Discurso para a Associaçáo Britânica de Literatura Comparada (British Comparative Literature Association - BCLA), 2006. Disponível em: <http://muse.jhu.edu/journals/comparative_critical_studies/ v003/3.1bassnett.html>. Acesso em: 28 set. 2015.

BHABHA, Homi K. O local da cultura. Tradução Myriam Ávila et al. Belo Horizonte: UFMG, 1998.

BOSI, Alfredo. História concisa da literatura brasileira. 44. ed. São Paulo: Cultrix, 2007.

CAPES. História e missão. 2017. Disponível em: <http://www.capes.gov. br/historia-e-missao>. Acesso em: 26 de abril 2017.

CARVALHAL, Tania Franco. A nação em questão: uma leitura comparatista. In: SCHMIDT, Rita T. (Org.). Naçóes/narraçóes: nossas histórias e estórias. Porto Alegre: Associação Brasileira de Estudos Americanos, 1997. p. 293-301.

Literatura Comparada e Estudos Culturais. In: O próprio e o alheio: ensaios de literatura comparada. São Leopoldo: Universidade do Vale do Rio dos Sinos, 2003. p. 203-215.

CARVALHO, José Murilo de. Fundamentos da política e da sociedade brasileiras. In: AVELAR, Lúcia; CINTRA, Antônio Octávio. Sistema político brasileiro: uma introdução. 2. ed. rev. ampl. Rio de Janeiro: Konrad-Adenauer-Stifung; São Paulo: Editora Unesp, 2007. p. 19-34.

CASANOVA, Pascale. A república mundial das letras. Tradução de Marina Appenzeller. São Paulo: EstaçãoLiberdade, 2002.

EVEN-ZOHAR, Itamar.Teoria dos polissistemas. Revista Translatio, 4, p. 2-21. Traduçáo de Luis Fernando Marozo, Carlos Rizzon e YannaKarllaCunha. Disponível em: <http://www.tau.ac.il/-itamarez/ works/papers/trabajos/Portugues/Even-Zohar_2013--Teoria\%20dos\%20 polissistemas.pdf $>$. Acesso em: 14 set. 2015.

HALLEWELL, Laurence. O livro no Brasil: sua história. Tradução de Maria da Penha Villalobos, Lólio Lourenço de Oliveira e Geraldo Gerson de Souza. 3. ed. São Paulo: Editora da Universidade de São Paulo: 2012. 
HABERMAS, Jürgen. Era das transiçóes. Tradução de Flávio Beno Siebeneichler. Rio de Janeiro: Tempo Brasileiro, 2003.

HARVEY, David. Condição pós-moderna. Tradução de Adail Ubirajara Sobral e Maria Stela Gonçalves. São Paulo: Loyola, 1992.

HOBSBAWM, E.; RANGER, T. (Orgs.). A invençáo das tradiçóes. Tradução de Celina Cavalcante. Rio de Janeiro: Paz e Terra, 1984.

HOBSBAWM, Eric. Era dos extremos: o breve século XX (1914-1991). Tradução de Marcos Santarrita. São Paulo: Companhia das Letras, 1995.

HUMBOLDT, Wilhelm von. Introdução a Agamêmnon - excerto de O Agamêmnon de Ésquilo em tradução em versos por Wilhelm von Humboldt (Leipzig, Editor Gerhard Fleischer, o Jovem). Tradução de Susana KampffLages. In: HEIDERMANN, Werner (Org.). Clássicos da teoria da tradução: antologia bilíngue alemão - português. v. 1. 2. ed. rev. ampl. Florianópolis: UFSC / Núcleo de pesquisa em literatura e tradução, 2010. p. 105-119.

IBGE. Tendências demográficas no período 1950 a 2000. Disponível em: <http://www.ibge.gov.br/home/estatistica/populacao/censo2000/ tendencias_demograficas/comentarios.pdf>. Acesso em: 6 dez. 2016.

JAMESON, Fredric. Pós-modernismo: a lógica cultural do capitalismo tardio. Tradução de Maria Elisa Cevasco. 2. ed. São Paulo: Ática, 1997.

KLIKSBERG, Bernardo. Repensando o Estado para o desenvolvimento social: superando dogmas e convencionalismos. Tradução de Joaquim Ozório Pires da Silva. São Paulo: Cortez, 1998. Disponível em: <http:// unesdoc.unesco.org/images/0013/001314/131428POR.pdf>. Acesso em: 5 dez. 2016.

LARRATEA, Marcelo Gomes. Elitesuniversitárias e as políticas de PósGraduaçáo no Brasil. 2012. Tese (Doutorado em Ciência Política) UniversidadeFederaldoRio GrandedoSul, PortoAlegre, 2012.Disponívelem: <https://www.lume.ufrgs.br/bitstream/handle/10183/61215/000862282. pdf?sequence $=1>$. Acesso em: 26 abr. 2017.

LEFEVERE, André. Pré-escrever. In: Traduçáo, reescritura e manipulação da fama literária. Tradução de Claudia Matos Seligmann. Bauru: Edusc, 2007. p. 13-27. 
MINISTÉRIO DA EDUCAÇÃO. Análise sobre a expansão das universidades federais 2003 a 2012: relatório da Comissão Constituída pela Portaria no 126/2012. Disponível em: <http://portal.mec.gov.br/ index.php?option=com_docman\&view=download \&alias=12386-analiseexpansao-universidade-federais-2003-2012-pdf\&Itemid=30192>. Acesso em: 26 abr. 2017.

RODRIGUES, Sara Viola. Tradução cultural: o que acontece em Um castelo no pampa, de L. A. de Assis Brasil. Organon, Porto Alegre, v. 17, p. 109-114, dez. 2003.

SCHMIDT, Rita Terezinha. Entrevista concedida a Jaime Ginzburgem em 2 de maio de 2016. Teresa - Revista de Literatura Brasileira, São Paulo, n. 17, p. 251-264, 2016.

Imaginário, voz e autoria feminina na literatura (entrevista a Priscila Pasko). Nonada, 05 nov. 2015. Disponível em: <http://www.nonada.com. br/2015/11/imaginario-voz-e-autoria-feminina-na-literatura/>. Acesso em: 26 abr. 2017.

Repensando a literatura comparada enquanto campo de singularidade e inovaçáo. In: BITTENCOURT, R. L. F.; SCHMIDT, R. T. (Orgs.). Fazeres indisciplinados: estudos de literatura comparada. Porto Alegre: UFRGS, 2013. p. 297-311.

SCHWARZ, Roberto. Nacional por subtração. In: SCHWARZ, Roberto. Cultura e política. São Paulo: Paz e Terra, 2001. p. 108-135.

SELIGMANN-SILVA, Márcio. Filosofia da tradução - tradução de filosofia: o princípio da intraduzibilidade. In: O local da diferença: ensaio sobre memória, arte, literatura e tradução. São Paulo: Editora 34, 2005. p. 167-188.

SILVA, Nélson do Valle; BARBOSA, Lígia de Oliveira. População e estatísticas vitais. In: IBGE. Estatísticas do século XX. Rio de Janeiro: IBGE, 2006. Disponível em: <http://biblioteca.ibge.gov.br/visualizacao/ livros/liv37312.pdf>. Acesso em: 2 nov. 2015.

STEINER, George. O que é literatura comparada? In: Nenhuma paixáo desperdiçada: ensaios. Traduçáo de Maria Alice Máximo. Rio de Janeiro; São Paulo: Record, 2001. p. 151-166. 
TORRES, Marie-Hélène Catherine. Traduzir o Brasil literário: história e crítica. v. 2. Traduçáo de Clarissa Prado Marini et. al. Tubarão: Copiart; PGET - UFSC, 2014.

VALLERIUS, Denise Mallmann. Borges em nova traduçáo: regionalismo para além das fronteiras. Porto Alegre: Editora da UFRGS, 2010.

Andrea Cristiane Kahmann <andreak.ufpb@gmail.com> Recebido: 29/04/2017 Aceito: 28/07/2017 